\title{
Fabrication of Gelatin/Chitosan/Zeolite Composite Packaging Film for Enhancing the Quality of Fresh Meat During Storage ${ }^{\dagger}$
}

\author{
Roopa Rajan ${ }^{1}$, Bincy P.K. ${ }^{2}$, Safeena M.P. ${ }^{1}$, T.K. Srinivasa Gopal ${ }^{3}$, Radhika Rajasree S.R. 1,* \\ 1 Department of Fish Processing Technology, Kerala University of Fisheries and Ocean Studies, Panangad, Kochi, Kerala- \\ 682506 \\ 2 Fish Processing Division, ICAR- Central Institute of Fisheries Technology, Kochi, Kerala- 682029 \\ 3 Centre of Excellence in Food Processing Technology, Kerala University of Fisheries and Ocean Studies, Panangad, Kochi, \\ Kerala- 682506 \\ * Correspondence: radhikarajasree@kufos.ac.in; \\ $\dagger$ Presented at International e-Conference on Bioengineering for Health and Environment (ICBHE 2020)
}

Received: 5.07.2020; Revised: 10.07.2020; Accepted: 12.07.2020; Published: 15.07.2020

\begin{abstract}
Valorisation of fishery by-products for the extraction of gelatin-like biopolymers is an active area of research presently due to their significant food and biomedical applications. In the present study, gelatin was extracted from the discarded portions of the Amphioctopusmarginatus. One of the major octopus species landed near the Kerala coast. Physico-chemical and functional characterization of the extracted gelatin was done based on SDS- PAGE, UV-Vis spectrophotometer, FTIR, XRD, HPLC, gelling and emulsifying capacities. Later, biocomposite film based on the gelatin/chitosan/zeolite was developed and characterized according to its solubility, opacity, spectroscopic analysis, antioxidative and antimicrobial activities. The results showed the dimensions of improving the properties of biopolymer films in terms of its ability to prevent the oxidative lipid changes, protein degradation and microbial spoilage in packaged fresh chicken meat over 9 days of refrigerated storage. The gelatin/chitosan/zeolite composite film thus developed has the potential to serve as a promising biobased packaging material in the food packaging and meat processing industries.
\end{abstract}

Keywords: Gelatin/Chitosan/Zeolite films; FTIR; HPLC; XRD; Meat storage; Food packaging materials.

\footnotetext{
(C) 2020 by the authors. This article is an open-access article distributed under the terms and conditions of the Creative Commons Attribution (CC BY) license (https://creativecommons.org/licenses/by/4.0/).
}

\section{Funding}

This research received no external funding.

\section{Acknowledgments}

This research has no acknowledgment.

\section{Conflicts of Interest}

The authors declare no conflict of interest. 